\title{
Fossils from the Silesian-Subsilesian series of the Polish Western Carpathians: the implications for changes in sea level and the marine environment during the Albian-Turonian
}

\author{
Andrzej SZYDŁO ${ }^{1, *}$, Małgorzata JUGOWIEC-NAZARKIEWICZ ${ }^{1}$ and Barbara OLSZEWSKA ${ }^{1}$ \\ 1 Polish Geological Institute - National Research Institute, Carpathian Branch, Skrzatów 1, 31-560 Kraków, Poland
}

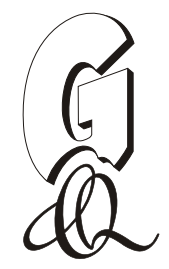

\begin{abstract}
Szydło, A., Jugowiec-Nazarkiewicz, M., Olszewska, B., 2015. Fossils from the Silesian-Subsilesian series of the Polish Western Carpathians: the implications for changes in sea level and the marine environment during the Albian-Turonian. Geological Quarterly, 59 (1): 215-228, doi: 10.7306/gq.1206

Foraminifera and calcareous nannoplankton, as well as other fossils from the Albian-Turonian deposits of the Western Polish Carpathians, are discussed in relation to changes in depositional environments, which were controlled by geotectonic activity, sea level changes, and anoxic and biotic events. The distribution and diversity of fossils in the deposits studied have been related to global sea level fluctuations or local sea level rise and fall. During the Albian to the Early Cenomanian, and in the Turonian, the local sea level falls led to an increased supply of coarse-grained material rich in siliceous and sometimes calcareous fossils and rock material. This cyclic process has contributed to changes in the marine biota. In the Albian, monospecific foraminiferal assemblages with a surficial infauna which colonized bottom waters after periods of organic influx and oxygen deficiency (OAE1b), evolved into more variable associations including deep infauna which indicate more aerobic conditions. Under these conditions planktonic and calcareous benthic fossils (tintinnids, calcareous nannoplankton, and foraminifera) were also preserved. Their presence was associated with the supply of terrigenous material from shallow-water environments and land, which were eroded during regressions controlled by local tectonic activity. During the AlbianTuronian transition, intense subsidence and volcanic activity associated with a relative sea level rise led to increased productivity of phytoplankton in the area studied. The sea-surface productivity and enhanced upwelling resulted in expanded short-term oxygen minima at the end of the Albian (OAE1d) and the Cenomanian (OAE2). In the latter interval benthic forms became almost extinct while siliceous and calcareous plankton survived. In the Turonian, changes in sea level and sedimentary regime led to re-colonization of the basin bottom.
\end{abstract}

Key words: Cretaceous, fossils, environments, sea level, Polish Carpathians.

\section{INTRODUCTION}

Collision between the African and European-Asiatic plates led to important changes in global palaeogeography during the mid-Cretaceous (e.g., Erbacher and Thurow, 1997; Hay et al., 1999; Golonka et al., 2000; Stampfli et al., 2001; Stampfli and Borel, 2002; Cavazza and Wezel, 2003). At that time, the Tethys Ocean was closing and volcanic activity was unusually high. It was responsible for changes in ocean circulation, sea level, the carbon cycle, and sea-surface productivity or preservation conditions (Bralower and Thierstein, 1984; Haq et al., 1988; Vogt, 1989; Calvert and Pederson, 1992; Erbacher et al., 1999, 2001; Golonka and Krobicki, 2001; Herrle et al., 2003). All these external factors were responsible for the greenhouse conditions in the mid-Cretaceous. At that time massive deposition of organic matter in marine environments resulted in the formation of organic-rich deposits (black shales) (Schlanger

\footnotetext{
* Corresponding author, e-mail: andrzej.szydlo@pgi.gov.pl Received: January 10, 2014, accepted: July 23, 2014; first published online: December 18, 2014
}

and Jenkyns, 1976; Arthur et al., 1990). The widespread distribution of black shales has been regarded as reflecting Oceanic Anoxic Events (OAEs) (Schlanger and Jenkyns, 1976). Its impact on biotic evolution in the ocean was dependent on how relative sea level coincided with the nutrient supply. The flooding of neighbouring lands and the input of nutrients during a relative rise of sea level led to increased productivity and expansion of the oxygen minima. Under these dysaerobic conditions, deepdwelling forms became extinct. Shallower dwelling radiolarians and planktonic foraminifers survived (Leckie, 1987; Erbacher et al., 1999; Robaszyński et al., 2010). The determination of the oxygen minima has been correlated with the uplift of lands and relative sea level falls, corresponding with a decreased nutrient supply, which led to the development of new deep habitats and to the radiation of deep-dwelling forms (Erbacher and Thurow 1997; Erbacher et al., 1999).

The above-mentioned model allows for the correlation of micropalaeontological data and different types of organic-rich shale, which reflect the OAEs and sea level fluctuations in the marine environment. It was used to explain the expansion of the oxygen minimum zone (OMZ), which caused the extinction and radiation of foraminifers and radiolarians in the mid-Cretaceous and the Cenomanian-Turonian transition in the North Atlantic and the western Tethys (Erbacher and Thurow, 1997; Erbacher 


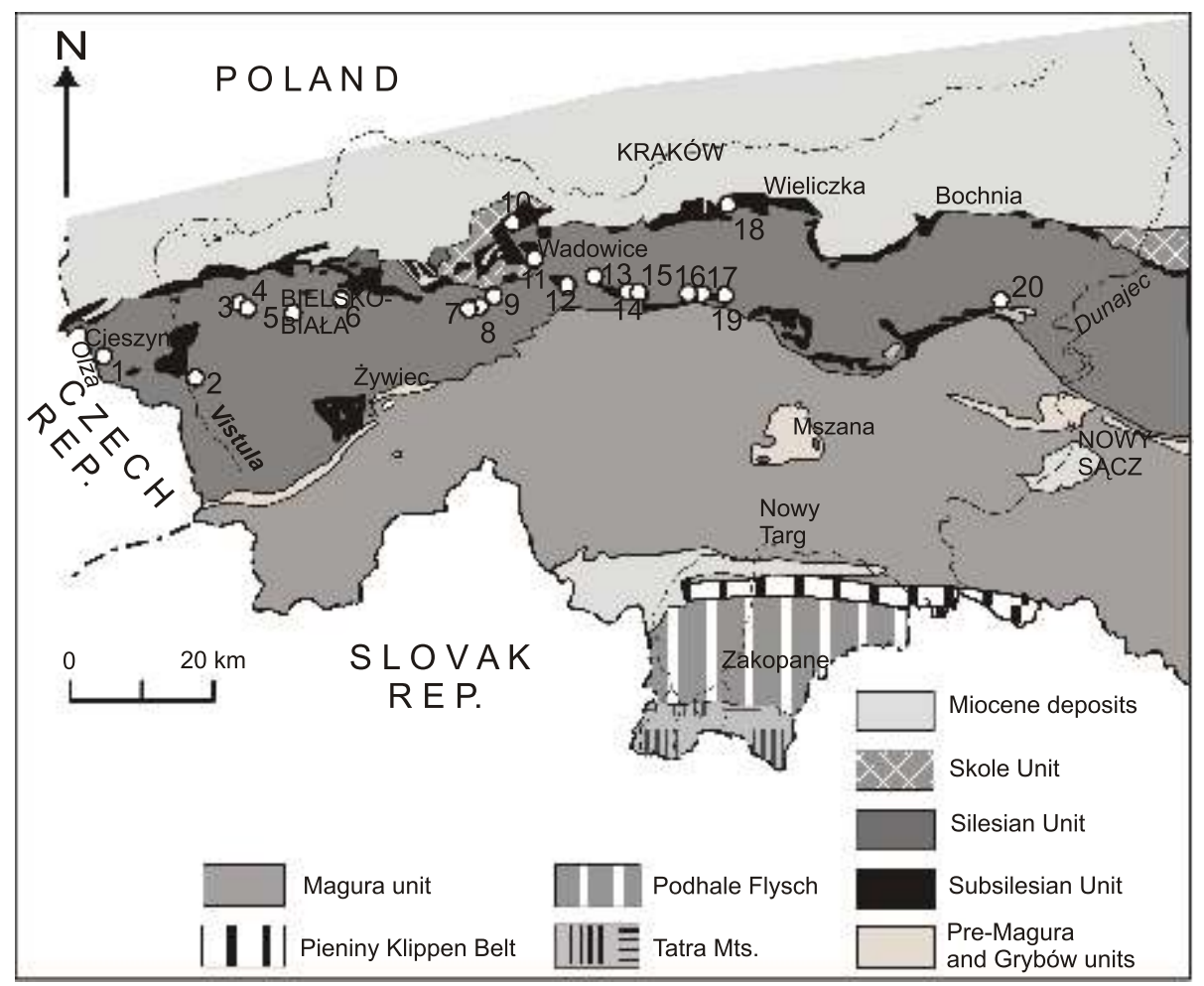

Fig. 1. Location of outcrops studied in the context of the tectonic units of the Polish Outer Carpathians (modified from ytko et al., 1989)

1 - Cisownica-3, 2 - Ustroń, 3 - Jasienica, 4 - Jaworze, 5 - Lipnik, 6 - Kozy, 7 - Bolęcin, 8 Rzyki, 9 - Kaczyna, 10 - Woźniki, 11 - Klecza, 12 - Barwałd Górny, 13 - Bugaj, 14 - Brody, 15 Lanckorona, 16 - Bysina, 17 - Barnasiówka, 18 - Lusina, 19 - Myślenice, 20 - Rajbrot

et al., 1999). An attempt to apply this model to reconstructions of the environmental and sea level fluctuations during the Albian-Turonian in the Western Outer Carpathian Basin has been proposed. The northern part of this area included marginal seas, which were especially sensitive to geotectonic instability and changes in sea level during the mid-Cretaceous (Birkenmajer and Gasiński, 1992; Ślączka et al., 1999). In the Subsilesian and Silesian sub-basins the dynamic and rapid deposition of siliciclastic sediments alternated with hemipelagic and pelagic sedimentation of organic-rich shales, which partly correspond to anoxic facies.

The formation of organic-rich siliciclastic deposits, which contain numerous and variable mineralised skeletal parts or components, and also crushed fragments of skeletons belonging to microfossils (foraminifers, radiolarians, sponges, dinocysts), macrofossils (bivalves, belemnites, ammonites) and nannofossils (calcareous nannoplankton), has been analysed in relation to changes in the marine environment, supplies of clastic material, and organic matter in the basin.

\section{GEOLOGICAL AND BIOSTRATIGRAPHICAL SETTINGS}

Rock material was sampled from the Albian-Turonian deposits, including coarse-grained sandstone successions intercalated with shales or separate formations of dark green radiolarian and variegated shales, which occur in the SilesianSubsilesian zone of the Western Outer Carpathians in Poland.
The deposits described are accessible in profiles located in the Beskid Śląski: Cisownica-3, Ustroń, Jaworze, Jasienica; the Beskid Mały: Lipnik, Kozy, Bolęcin, Rzyki, Kaczyna, Buldonówka; Lanckorona Foothills: Lusina, Woźniki, Klecza, Bugaj, Brody, Barwałd Górny, Lanckorona; the Beskid Średni: Bysina, Barnasiówka, Jasienica near Myślenice, and also the Beskid Wyspowy: Rajbrot. With the exception of the Woźniki, Barwałd Górny, Lusina, Jasienica near Myślenice, and Rajbrot sections that contain the Subsilesian Series, in the exposures listed only deposits of the Silesian Unit occur (Fig. 1).

In the area studied, located between the Olza and the Dunajec rivers, the deposits sampled belong to the AlbianTuronian Lgota and Gaize beds, the Turonian-lowermost Turonian green radiolarian shales, and the Turonian Godula Beds and variegated marly shales (Ślączka et al., 1993; Bąk et al., 2001; Fig. 2). The so-called Lgota Beds include three lithostratigraphical units. There are coarse-grained sandstones of Early Albian age containing carbonate and magmatic rocks, spicule-rich sandstones intercalated with dark, non-calcareous shales of the Middle-Late Albian age, and spongiolites of Late Albian-Turonian age (Koszarski and Nowak, 1960; Bieda et al., 1963; Geroch et al., 1967). The lower and uppermost parts of the Lgota Beds occur only in the western part of the study area. Sandstone series intercalated with shales, that are typical of the middle and partly upper part of this lithostratigraphical unit, are exposed in the remaining areas. The Lgota Beds are replaced locally by the Gaize Beds, consisting of sponge spicules in the northern and sporadically in the eastern uplifted parts of the Silesian Basin, which formed as the Subsilesian sub-basin in Cenomanian-Turonian time (Bieda et al., 1963; Geroch et al., 


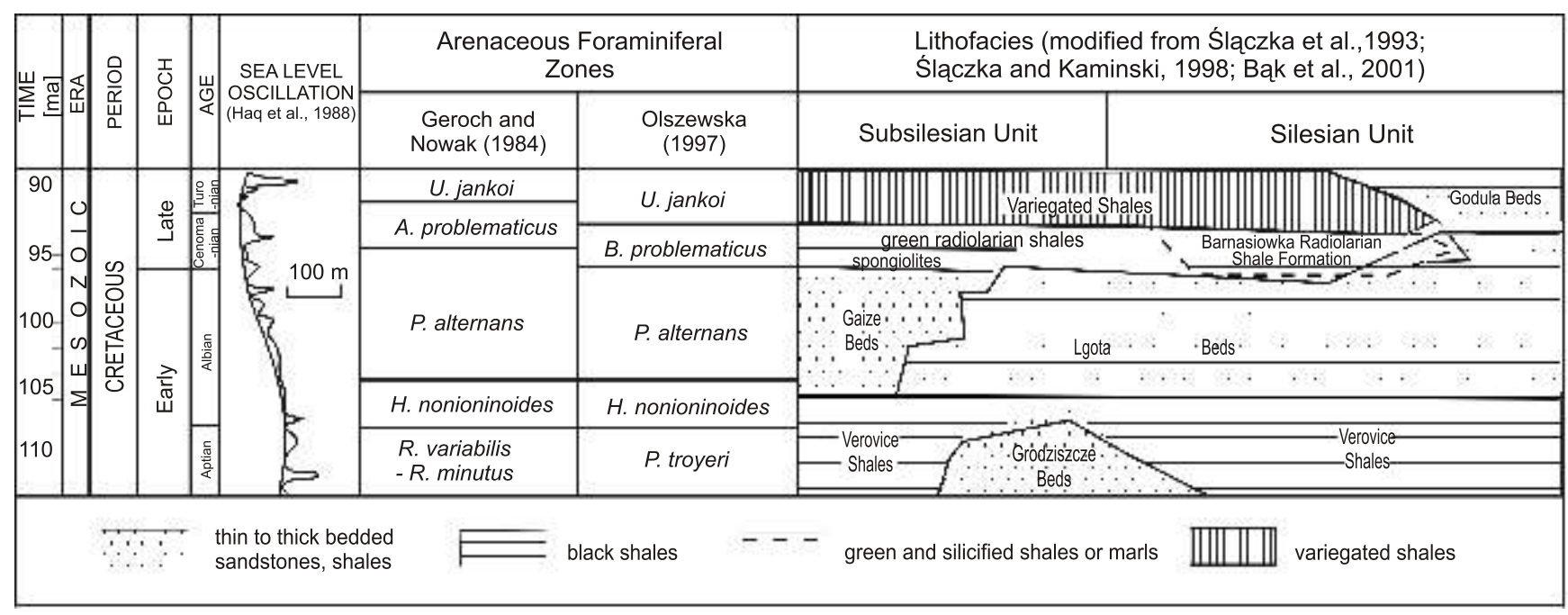

Fig. 2. Lithology and stratigraphical position of the studied series of the Silesian and Subsilesian units

1967; Alexandrowicz, 1973). In the Cenomanian, ferromanganese and green radiolarian shales were typical of open seas in the Silesian Basin while variegated biosiliceous marly shales and silicified marls and bioturbated limestone occurred in the Subsilesian zone. This succession, which is traditionally known as the radiolarian beds, was partly assigned to the Barnasiówka Radiolarian Shale Formation by Back et al. (2001). The biosiliceous deposits, including tuffites and bentonites, locally persisted to the earliest Turonian (Bak, 2000), at which time the deposition of the Jasienica marls ceased (Liszkowa, 1972). In the Turonian, coarse clastic turbidites (Godula Beds) were deposited again in the western part of the Outer Carpathian Basin, which was divided into diverse zones of deposition (Silesian, Lanckorona and Wieliczka zones; Ksia kiewicz, 1962). In the initial stage of this deposition, thick-bedded sandstones dominated (Silesian zone). The sandstone succession was intercalated with variegated calcareous shales, which became the dominant facies in the central part of the basin (Silesian zone) and at its northern and eastern margins (Lanckorona and Wieliczka zones; Koszarski et al., 1959; Ksią kiewicz, 1962; Słomka, 1995).

The Albian-Turonian series include biosiliceous and siliceous coarse-grained turbidites (Lgota Beds, Gaize Beds and Godula Beds) and also green and variegated shales and marls, which contain numerous sponge spicules, radiolarians, foraminifers, dinocysts, benthic and nektonic macrofauna (bivalves, belemnites and ammonites), and carbonate and crystalline blocks (Ksią kiewicz, 1962). Among them, foraminifers, radiolarians, and dinocysts are usually used for biostratigraphy of the deposits studied (Koszarski et al., 1959; Koszarski and Nowak, 1960; Geroch, 1966; Geroch et al., 1967; Geroch and Nowak, 1984; Olszewska, 1997; Bąk, 2000; Bąk et al., 2000, 2005; Gedl, 2001, 2003).

\section{MATERIAL AND METHODS}

The paper is partly based on the study of rock material taken mainly from siliceous, marly, or limy shales, and sometimes bioand siliceous sandstones. The collected shaly samples were disintegrated by boiling and freezing. The $63 \mu \mathrm{m}$ fraction was used for micropalaeontological analysis. The study of the selected microfossils (foraminifers, radiolarians, and sponge spicules) was performed under a stereoscopic optical microscope (Zeiss Stereo Discovery. V12). In addition, the smear-slides for calcareous nannoplankton investigations and the thin-sections for micropalaeontological analysis (foraminifers, tintinnids, calcareous dinocysts, and algae) were analysed using polarizing optical microscopes. Photographic documentation was performed using optical microscopes made by Nikon and Zeiss.

The collected micro- and nannofossils were described with a special focus on the relationship between test morphology and living or feeding strategy, and also ecological preferences and fossilisation potential. These results are compared with sea level and oxygenation changes in the marine environments.

\section{RESULTS}

The Albian-Turonian deposits contain diverse micro- and macrofossils. Foraminifers are the most widespread group in the deposits. This microfauna includes primarily autochthonous forms agglutinated by silica, and also ones with calcareous cement and planktonic and calcareous benthic forms (Huss, 1957; Geroch, 1966; Geroch and Nowak, 1984; Olszewska, 1997; Bak et al., 2005; Szydło, 2008). Agglutinated forms are numerous, while calcareous forms occur in low numbers. Periodically siliceous skeletal elements of sponges and radiolarians co-occur with them or replace them. These siliceous microfossils are mainly components of spongiolites, cherty mudstones, and green radiolarian shales (Geroch, 1966; Geroch et al., 1967; Geroch and Nowak, 1984; Olszewska, 1997; Górka and Geroch, 1998; Bak, 2000). Moreover, the silica originating from the dissolution of these elements cemented mainly sandstones and conglomerates, and sometimes marly shales belonging to the Lgota and the Godula beds. Similarly to the siliceous microfossils, dinocysts occur frequently. These organic-walled microfossils occur in the Albian-Turonian sandstone series and also in the Cenomanian-Turonian successions (Gedl, 2001, 2003). Important components of fossil assemblages are calcareous nano- and microflora and also macrofauna, which occur periodically. Calcareous zooplankton (tintinnids) and phytoplankton (dinocysts) were described for the first time in the deposits studied while macrofauna (bivalves, 
ammonites and belemnites) had been reported earlier (Koszarski et al., 1959; Koszarski and Nowak, 1960).

The oldest foraminiferal assemblage that is dominated by numerous specimens of Recurvoides pseudononioninoides Neagu (= Haplophragmoides aff. nonioninoides sensu Geroch, 1966; Neagu and Platon, 1994) is widely distributed in the lower and middle part of the Lgota Beds of the Silesian and the Subsilesian units (comp. with Geroch, 1966; Szydło, 2008; Figs. 3 and 4). The mass occurrence of this taxon is known from the underlying Verovice Beds and corresponds with the agglutinated foraminiferal zone of $\mathrm{Hpl}$. nonioninoides, dated to the Early Albian age (Geroch and Nowak, 1984; Olszewska, 1997; Fig. 2). According to Szydło (2008), the rare taxa belonging to genera Jaculella, Hyperammina, Ammodiscus, Glomospira, Saccammina, Caudammina, Haplophragmoides, Thalmannammina, Trochammina, Gaudryina, and Pseudobolivina are locally accompanied by the index species in the lower part of the Lgota Beds (Cisownica-3, Jaworze, Lipnik, Kozy; Fig. 3).

In these successions few and poorly preserved radiolarians belonging mainly to the genera Nasellaria, Dictyomitra, Stichocapsa, Stichocampe, and sometimes Spumellaria, Cenellipsis, and Cenosphaera are also present (Geroch, 1966; Górka and Geroch, 1989). In these deposits macrofauna also occurs. This is represented by forms belonging to Inoceramus, single ammonites referable to Acanthoplites bigoureti (Early Albian), and also numerous belemnite rostrae, which are correlated with the mass occurrence zone of Neohibolites minimus (Middle Albian; Figs. 3 and 4). In the western part of the Polish Outer Carpathians, this macrofauna is known from the Straconka and Lipnik localities in Beskid Mały (Koszarski and Nowak, 1960; Szymakowska, 1980).

This macrofauna suggests that the lower part of the Lgota Beds was mainly deposited in the Early Albian and partly also in the Middle Albian. At the time, tintinnids (Colomiella recta, $C$. semiloricata; Fig. 5A, B) and calcareous dinocysts (Colomisphaera heliosphaera; Fig. 5C, see Appendix $1^{*}$ ) locally occur in marls (Jasienica near Myślenice, Subsilesian Unit; Olszewska, 1997; Fig. 4). These deposits were regarded as the Jasienica marls that locally persisted into the latest Turonian (Liszkowa, 1972).

In places, the assemblage with $R$. pseudononioninoides survived until the end of the succession in low frequency (Jaworze, Rzyki, Bysina, Barnasiówka localities; Figs. 3 and 4). In the middle and upper parts of the Lgota Beds, this assemblage is usually replaced by the Late Albian association composed of the species $P$. alternans and $R$. imperfectus and G. filiformis (see Appendix 1) in the Lipnik and Kaczyna localities (Fig. 3). The assemblage described also contains numerous specimens of the genera Plectorecurvoides and Thalmannammina (Lipnik, Bolęcin; Fig. 3). This microfauna corresponds to the $P$. alternans Zone, which is correlated with the Middle Albian-Cenomanian by Geroch and Nowak (1984), or the Late Albian by Olszewska (1997) (Fig. 2). In the latter cases, the upper part of the zone was marked by the first occurrence (FO) of Bulbobaculites problematicus towards the end of the Early Cretaceous (Figs. 3 and 4). In Beskid Mały and in the Lanckorona Foothills the Lgota Beds contain arenaceous microfauna, which are represented by the species Haplophragmoides falcatosuturalis (Lipnik, Lanckorona Geroch, 1966; borehole Łodygowice IG-1 - Geroch and Nowak, 1980) and Arenobulimina chapmani (Kozy, Fig. 3; Brody, Fig. 4). These Albian forms may still be present in the Cenomanian. Single specimens of calcareous foraminifera of the genera Lenticulina and Pseudonodosaria locally co-occur with them (Jaworze-Jasienica area and Kozy; Fig. 3).
In the upper part of the Lgota Beds, siliceous microfauna is replaced by calcareous foraminifers, including planktonic and benthic forms. The first simple inflated forms belong to Hedbergella delrioensis, $\mathrm{H}$. infracretacea and Heterohelix moreman (Lipnik, Bolęcin, Barnasiówka; Fig. 3) and others are represented by the genus Rotalipora (Klecza Dolna, Fig. 4, see Appendix 1). The benthic forms include Osangularia (O. brotzeni, O. schloenbachi), Lenticulina, Gyroidinoides, Discorbis, Cibicides (Cisownica-3, Lipnik, Bysina, Figs. 3 and 4; cf. with Geroch, 1966). The calcareous foraminifer tests are often small and poorly preserved, showing traces of dissolution and corrosion.

Numerous spicules of sponges and very rare radiolarians (Spumellaria) occur next to foraminifera in the deposits discussed. Radiolarians and calcareous foraminifers are preserved usually as moulds composed of pyrite (Geroch, 1966; Bąk, 2000).

Additionally, organic-walled dinocysts occur in the Lgota Beds. According to Gedl (2003) these forms, occurring above thick-bedded sandstones, correspond to the Palaeohystrichophora infusorioides Zone of Late Albian age and they are correlated with the Albian-Turonian transition (Epelidophaeridia spinosa Zone) in the upper part of the Lgota Beds (Gedl, 2003). Generally, palynofacies occurring in the lower part of the Lgota Beds are dominated by forms belonging to Pterodinium and by diversified endocysts belonging to the genera Ovoidinium, Odontichitina, Muderongia, Apteodinium, Canningia, Cyrculodinium, Pseudoceratinium, and also peridinioids (Lipnik; Gedl, 2001, 2003). Peridinioids also dominate in the upper part of the Lgota Beds. Along with the dominant Palaeohystrichophora infusorioides there co-occur numerous black organic objects (phytoclasts) (Lipnik, Rzyki, Barnasiówka; Gedl, 2003). At the top of this succession blooms of Pseudoceratinium, Subtilisphaera, and Ovoidinium are noted (Lipnik, Kozy, Rzyki).

In spicule-rich deposits, which are assigned to the Gaize Beds, the number and diversity of the foraminifers distinctly decrease. The microfauna is represented by calcareous benthic foraminifera of the Albian-Turonian (Berthelina intermedia, $B$. berthelini, Gyroidinoides infracretaceus, Valvulineria loetterlei, Patellina subcretacea). Part of them is poorly preserved. These forms belong to the genera Lagena and Cibicides (KleczaBabica and Woźniki localities; Fig. 4) or Guttulina and Planularia (Barwałd; Fig. 4). Planktonic foraminifers belonging to Rotalipora co-exist with them (cf. Liszkowa, 1956; Huss, 1957). In these biosiliceous rocks, calcareous nannoplankton have been reported. In the vicinity of Barwałd Górny (Fig. 4), reworked Jurassic species occur (Watznaueria barnesae, Polypodorhabdus escaigii, Ellipsogelosphaera britannica, Zeugrhabdotus erectus, Cretarhabdus conicus, Stephanolithion atmetos, C. crenulatus, Lotharingius hauffii, Crepidolithus granulatus, and specimens of Manivitella pemmatiodea; Fig. 6, see Appendix 1) known from the Hauterivian; in addition, calcareous benthic foraminifers belonging to the genera Guttulina, Planularia, and Lenticulina are described. Moreover, calcareous nannoplankton including long-lived forms (Vagalapilla matalosa, Watznaueria barnesae, Glaukolithus diplogrammus), and those from the Barremian (Gl. compactus) and the Albian-Turonian (Prediscosphaera columnata) are reported from Woźniki (Figs. 4 and 6, see Appendix 1). The assemblages described correspond to intervals CC8 and the CC9. In the same sample, agglutinated foraminifers belonging to $B$. problematicus, the FO of which is located in the highest Albian, were found.

In silicified variegated shales and marls, as opposed to spongiolites, there occur not only radiolarians and sponge spicules but also planktonic forms. The dominant component of 


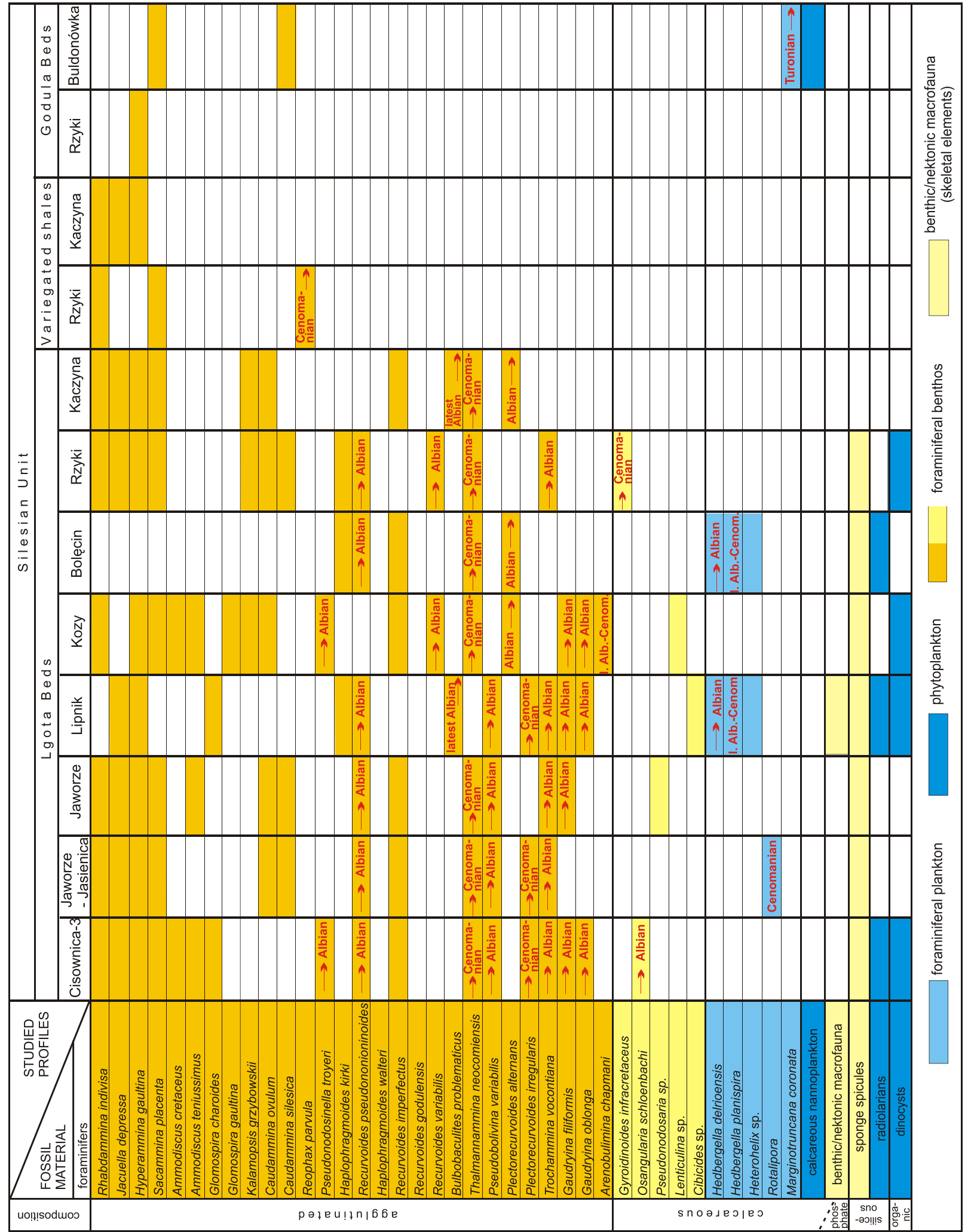

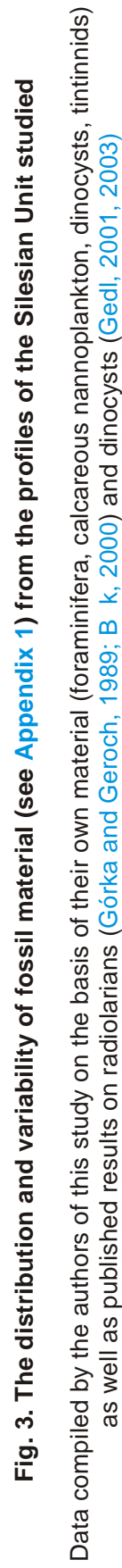




\begin{tabular}{|c|c|c|c|c|c|c|c|c|c|c|c|c|c|c|}
\hline \multirow{3}{*}{\multicolumn{2}{|c|}{ 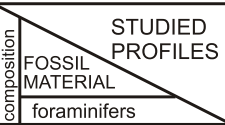 }} & \multicolumn{8}{|c|}{ Silesian Unit } & \multicolumn{5}{|c|}{ Subsilesian Unit } \\
\hline & & \multirow[b]{2}{*}{ Klecza DIn. } & \multicolumn{3}{|c|}{ Lgota Beds } & \multirow[b]{2}{*}{ Bysina } & \multirow[b]{2}{*}{ Barnasiówka } & \multicolumn{4}{|c|}{ Variegatedshales and marls } & \multicolumn{3}{|c|}{ GaizeBeds } \\
\hline & & & Bugaj & Brody & Lanckorona & & & \begin{tabular}{l|} 
Klecza \\
- Babica
\end{tabular} & Lanckorona & \begin{tabular}{|c|} 
Jasienica \\
n. Myślenice
\end{tabular} & Rajbrot & Woźniki & Lusina & $\begin{array}{c}\text { Barwałd } \\
\text { Grn. }\end{array}$ \\
\hline \multicolumn{15}{|c|}{\begin{tabular}{|l|l|} 
R. indivisa & \\
\end{tabular}} \\
\hline \multirow{2}{*}{\multicolumn{15}{|c|}{\begin{tabular}{|l} 
J. depressa \\
$H$. daultina
\end{tabular}}} \\
\hline \multirow{2}{*}{\multicolumn{15}{|c|}{ S. placenta }} \\
\hline & & & & & & & & & & & & & & \\
\hline \multicolumn{15}{|c|}{ A. cretaceus } \\
\hline \multirow{2}{*}{\multicolumn{15}{|c|}{ A. teniussimus }} \\
\hline & & & & & & & & & & & & & & \\
\hline & G. gaultina & & & & & & & & & & & & & \\
\hline & K. grzybowskii & & & & & & & & & & & & & \\
\hline & C. ovulum & & & & & & & & & & & & & \\
\hline & C. silesica & & & & & & & & & & & & & \\
\hline ¿ & Reophax sp. & & & & & & & & & & & & & \\
\hline ๘ & P. troyeri & & & & & $\begin{array}{l}\text { Cenomanan } \\
\rightarrow \text { Albiann } \\
\end{array}$ & $\begin{array}{l}\text { Cenomanala } \\
\rightarrow \text { Albian } \\
\end{array}$ & & & & & & & \\
\hline E. & H. kirki & & & & & & & & & & & & & \\
\hline I & R. pseudononioninoides & $\rightarrow$ Albian & $\rightarrow$ Albian & $\rightarrow$ Albian & & $\rightarrow$ Albian & $\rightarrow$ Albian & & & & & & & \\
\hline of & H. walteri & & & & & & & & & & & & & \\
\hline & R. imperfectus & & & & & & & & & & & & & \\
\hline & R. godulensis & Cenom.-Turor & & & & & & Cenom.-Turon & Cenom.-Turon & & & & & \\
\hline & R. variabilis & Cenom.-Turon & & & & & & Cenom.-Turon. & Cenom.-Turon & & & & & \\
\hline & B. Problematicus & & & & & & & & & & & $\begin{array}{l}\text { latest } \\
\text { Albian }\end{array} \longrightarrow$ & & \\
\hline & T. neocomiensis & $\rightarrow$ Cenoman & $\rightarrow$ Cenomar & $\rightarrow$ Cenoman & & $\rightarrow$ Cenoman & & & $\rightarrow$ Cenoman. & & & & & \\
\hline & Ps. variabilis & & $\rightarrow$ Albian & & & & & & & & & & & \\
\hline & $P$. alternans & & & & Albian $\longrightarrow$ & Albian $\longrightarrow$ & Albian $\longrightarrow$ & & & & & & & \\
\hline & P. irregularis & & & & & & & & & & & & & \\
\hline & T. vocontiana & & $\rightarrow$ Albian & & & $\rightarrow$ Albian & $\rightarrow$ Albian & & & & & & & \\
\hline & G. filiformis & & & & & $\rightarrow$ Albian & $\rightarrow$ Albian & & & & & & & \\
\hline & G. oblonga & & & & & $\rightarrow$ Albian & $\rightarrow$ Albian & & & & & & & \\
\hline & G. tailleuri & Alb.Turon. & & & & & & & Alb.-Turonian & & & & & \\
\hline & F. moesiana & & & & & & & & Albian ${ }_{\text {Conmanian }}^{\text {Co }} \uparrow$ & & & & & \\
\hline & U. jankoi & & & & & & & & $\begin{array}{l}\text { Iate } \\
\text { Cenomanian }\end{array}$ & & & & & \\
\hline & G. Ienis & & & & & & & & Turonian $\rightarrow$ & & & & & \\
\hline & A. chapmani & & & I. Alb.-Cenom & & 1. Alb.-Cenom. & & & & & & & & \\
\hline & V. lotterlei & & & & & & & & & & & & & \\
\hline & G. infracretaceus & $\rightarrow \rightarrow$ Cenoma- & & & & $\rightarrow \begin{array}{l}\text { Conoma- } \\
\text { nian }\end{array}$ & & $\rightarrow \begin{array}{c}\text { Cenoma- } \\
\text { nian }\end{array}$ & & & & & & \\
\hline & C. aptiensis & $\rightarrow$ Ailibian an & & & & & & & & & & & & \\
\hline & B. intermedia & $\begin{array}{l}\rightarrow \text { Ciliomananian } \\
\rightarrow \text { Albian }\end{array}$ & & & & & & & & & & 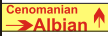 & & \\
\hline & O. brotzeni & & & & & mid.-1. Alb. & & & & & & & & \\
\hline & P. subcretacea & & & & & & & & & & & & & \\
\hline & Lagena sp. & & & & & & & & & & & & & \\
\hline & Cibicides sp. & & & & & & & & & & & & & \\
\hline is & Planularia sp. & & & & & & & & & & & & & \\
\hline 하 & Guttulina sp. & & & & & & & & & & & & & \\
\hline Ф & Lenticulina sp. & & & & & & & & & & & & & \\
\hline of & H. delrioensis & & & & & & & & & & & & & \\
\hline $\bar{\sigma}$ & H. infracretacea & & & & & & I.Albian $\longrightarrow$ & & & & & & & \\
\hline & H. moremani & & & & & & $\begin{array}{l}\text { L.Albian Turomian } \\
\end{array}$ & & & 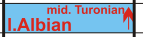 & & & & \\
\hline & Rotalipora & Cenomanian & & & & & & & & & & & & \\
\hline & G. cenomana & & & & & & & & & 1. Alb-1.Turonian & & & & \\
\hline & $\begin{array}{c}\text { calcareous } \\
\text { nannoplankton }\end{array}$ & & & & & & & & & & & & & \\
\hline & tintinnids & & & & & & & & & & & & & \\
\hline & calcareous dinocysts & & & & & & & & & & & & & \\
\hline 罣 & radiolarians & & & & & & & & & & & & & \\
\hline & sponge spicules & & & & & & & & & & & & & \\
\hline
\end{tabular}

Fig. 4. The distribution and variability of fossil material from the profiles studied of the Subsilesian Unit

Data compiled by the authors of this study, including their own results and the results on radiolarians and dinocysts published by Bąk $(2000)$ and Gedl $(2001,2003)$ respectively; for other explanations see Figure 3

planktonic associations is made of spherical skeletons of radiolarians belonging to the genera Holocryptocanium and Hemicryptocapsa (Bąk, 2000), as well as smaller conical forms of Dictyomitra, which appear rarely in the Lgota Beds of the Silesian Unit (cf. Geroch, 1966; Górka and Geroch, 1989). These forms, belonging to the Nassellaria and the Spumellaria (Praeconocaryomma, Patellula), occurred in the Late Cenomanian-Early Turonian (Back, 2000). In Albian-Cenomanian time, dinocysts and planktonic foraminifers co-existed with them. The first are calcareous forms belonging to the species Orthopithonella sphaerica and O. ovalis (Fig. 5D, E; Rajbrot, Subsilesian Unit; Olszewska, 1997), and organic-walled taxa (Silesian Unit; Bąk et al., 2000). Foraminiferal plankton, which are represented by forms typical of the Cenomanian (Schackoina, Rotalipora) and the Cenomanian-Early Turonian (Praeglobotruncana stephani), were described in green shales of the Subsilesian Unit occurring between and under radiolarites in Węglówka (Huss, 1957) and Tuchów, Targanice, and Czaniec Górny (Koszarski et al., 1959) respectively. In the green shales, which include radiolarites, planktonic forms belonging to the genera Hedbergella, Guembelitria, Hetereholix (Fig. 5F-H) were also noted at Rajbrot (cf. Olszewska, 1997).

In the Cenomanian variegated shales of the Silesian Unit, in which siliceous foraminifers are often lacking (Kaczyna; Fig. 3) planktonic foraminifers belonging to the genera Hedbergella and Heterohelix occur in low numbers (Barnasiówka; Fig. 4). In 

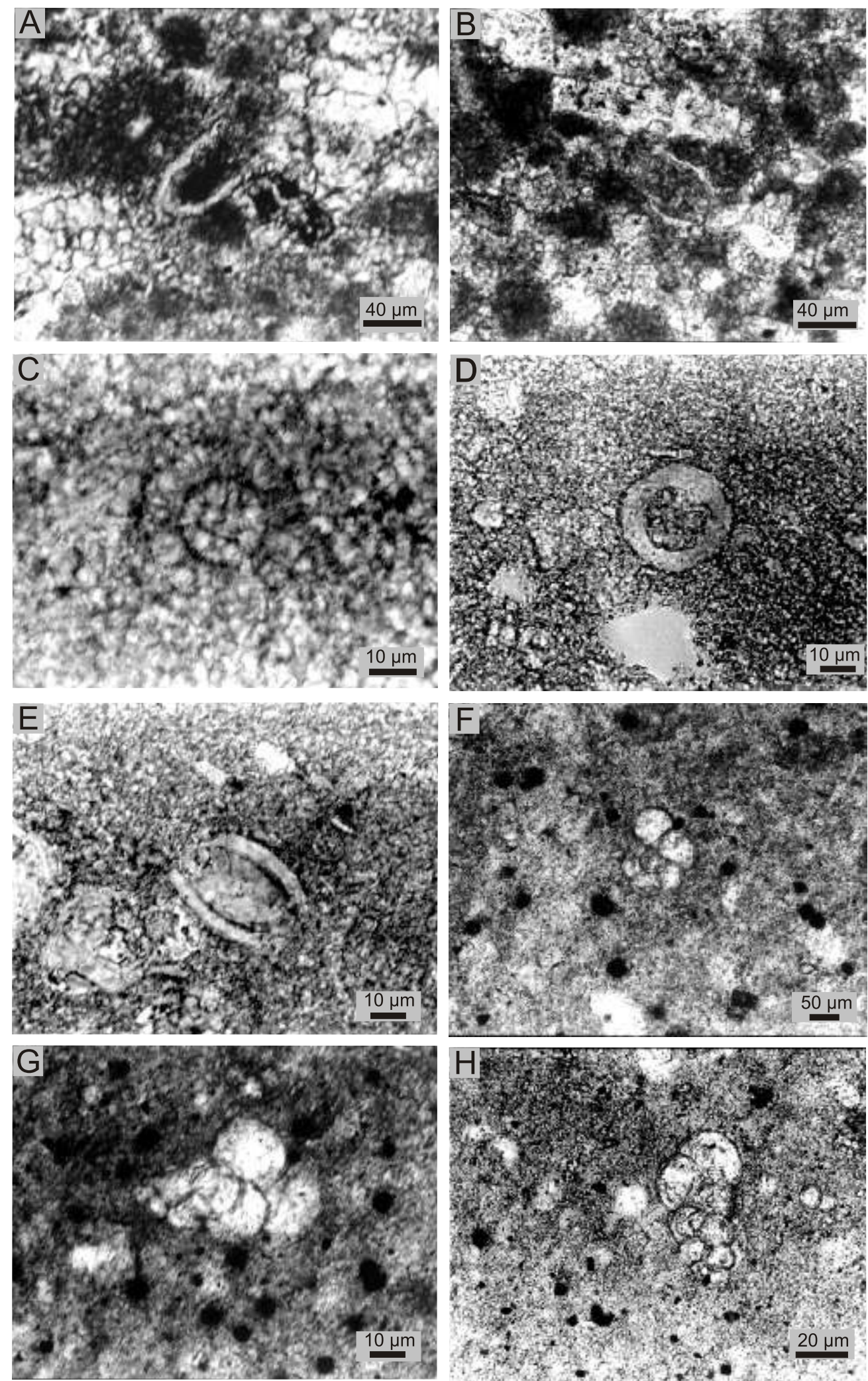

Fig. 5. Calcareous plankton including tintinnids, dinocyst and foraminifers

Tintinnids: A - Colomiella recta Bonet, B - C semiloricata Trejo (A, B - Jasienica n. Myślenice; Subsilesian Unit); calcareous dinocysts: C - Colomisphaera heliosphaera (Vogler), Jasienica n. Myślenice (Subsilesian Unit); D - Orthopithonella sphaerica (Kaufman); E - O. ovalis (Kaufman) (D, E Rajbrot; Subsilesian Unit); foraminifers: F - Hedbergella delrioensis Carsey, G - Guembelitria cenomana Keller; $\mathbf{H}$ - Heterohelix moremani (Cushman) (F-H - Rajbrot; Subsilesian Unit) 

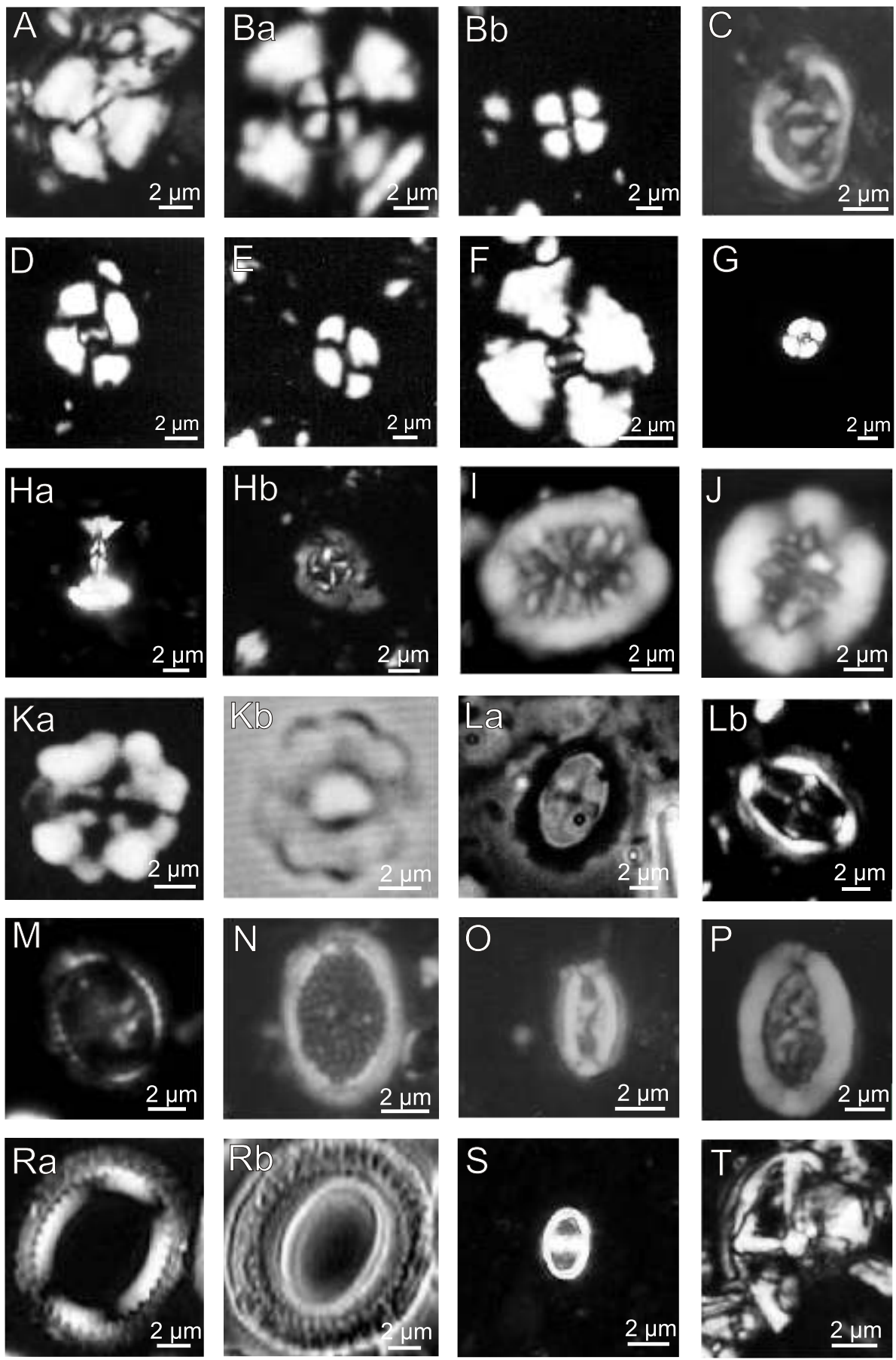

Fig. 6. Calcareous nannoplankton

A - Watznaueria barnesae (Barwałd Górny, Gaize Beds, Subsilesian Unit); Ba, Bb Cyclagelosphaera margerelii (Buldonówka, Godula Beds, Silesian Unit); C - Glaukolithus compactus (Woźniki, Gaize Beds, Subsilesian Unit); D - Ellipsagelosphaera lucasii; E - E. fossacincta; F - E. britannica; G - Lotharingius hauffii (D-G - Barwałd Górny, Gaize Beds, Subsilesian Unit); Ha, Hb - Prediscosphaera columnata (Woźniki, Gaize Beds, Subsilesian Unit); I - Cretarhabdus crenulatus (Barwałd Górny, Gaize Beds, Subsilesian Unit); J - Cr. conicus; Ka, Kb - Ephrolithus floralis (J, K - Buldonówka, Godula Beds, Silesian Unit); La, Lb Vagalapilla sp. (Woźniki, Gaize Beds, Subsilesian Unit); M - Polypodorhabdus escaigii (Barwałd Górny, Gaize Beds, Subsilesian Unit); N - Ethmorhabdus gallicus (Buldonówka, Godula Beds, Silesian Unit); O - Stephanolithion atmetos; $\mathbf{P}$ - Crepidolithus granulatus; $\mathbf{R a}, \mathbf{R b}$ - Manivitella pemmatoidea; S - Zeugrhabdotus erectus (O-S - Barwałd Górny, Gaize Beds, Subsilesian Unit); T - Vagalapilla matalosa (Woźniki, Gaize Beds, Subsilesian Unit) (see Appendix 1) 
calcareous shales of the same age, agglutinated forms (Recurvoide sgodulensis, $R$. variabilis, Thalmannammina neocomiensis, Uvigerinammina praejankoi or Bulbobaculites problematicus - see Appendix 1; Kaczyna, Klecza Dolna) co-exist with single specimens of Rotalipora (Rzyki; Figs. 3 and 4). Apart from these, Falsogaudryinella moesiana occurs very rarely (Lanckorona; Fig. 4). Its occurrence determines the age of the variegated shales as being of the earliest Cenomanian.

In the Turonian, these facies were replaced locally by thickbedded and coarse-grained sandstones, which are typical of the bottom of the Godula Beds (Słomka, 1995). In this part of the succession, macrofauna, including poorly preserved and crushed shells of ammonites and bivalves of the genus Inoceramus, occurs locally (Koszarski et al., 1959). In other areas, variegated shales, which occur as intercalations in the glauconitic sandstones, contain rare foraminifers. Single specimens of the planktonic Marginotruncana coronata, the FO of which corresponds to the Late Turonian, appear in the Outer Carpathian region (Buldonówka; Fig. 3). In the same sample, mixed and reworked calcareous nannoplankton belonging to the species $W$. barnesae, E. gallicus, Cyclagelosphaera margerelii, Cretarhabdus conicus and E. floralis are present (Fig. 6, see Appendix 1). The last form corresponds to the Aptian-Santonian interval (cf. Caron, 1985). In places, the Turonian Godula sandstones are intercalated with variegated shales containing agglutinated foraminifers: N. excelsa, C. ovulum, G. lenis and U. jankoi (Fig. 4, see Appendix 1; cf. Geroch et al., 1967).

\section{CHANGES IN THE DEPOSITIONAL ENVIRONMENTS}

In the Silesian-Subsilesian zone of the Outer Carpathian Basin, biosiliciclastic sedimentation prevailed during the Albian-Turonian. This sedimentary process was clearly related to geotectonic and volcanic activities, which resulted in relative sea level fluctuations and anoxic or biotic events (Ksią kiewicz, 1961, 1975; Gucwa and Wieser, 1980; Olszewska, 1984; Gucwa, 1990; Bak et al., 2001, 2005; Olszewska and Malata, 2006; Bakk, 2007; Szydło, 2008; Olszewska and Szydło, 2012). The availability of oxygen and organic matter content in depositional environments was also controlled by these settings. All these factors had strong influence on the evolution and distribution of biotopes and on fossilisation in the deposits. The fossils, especially calcareous forms, are generally poorly preserved in the deposits studied, and are strongly affected by diagenetic processes. Calcareous fossils include benthic and planktonic foraminifers, as well as nannoplankton, calcareous dinocysts, and the shells of bivalves and ammonites. Calcareous fossils similar to belemnites, siliceous skeletal elements of radiolarians and sponges and also organic dinocysts were reworked and mixed many times before they finally accumulated in the deposits. Calcareous or siliceous skeletons of benthic forms originated in shallow water environments, which were destroyed during the uplift of areas and the sea level falling, especially in the Early Albian and the Early Turonian, and locally in the Late Albian. The occurrence of the organic-walled dinocysts, which are characteristic of low salinity (Ovoidinium, Odontichitina, Muderongia) and terrestrial (peridinioids) environments, coincided with these events during the Albian. These organic-walled cysts had thin and delicate shells devoid of complex appendages (Gedl, 2003). Probably tintinnids belonging to Colomiella as index fossils for the Late Aptian-Early Albian (Longoria, 1973) co-existed with them (Jasienica near Myślenice, Subsilesian Unit; Olszewska, 1997; Figs. 3-5 and 7).

This bioclastic material was transported periodically by turbidity currents on slopes. In the initial stages of the process the coarse-grained sandstones of the Lgota, the Gaize, and the Godula beds accumulated. These deposits include the broken and crushed skeletons of benthic (bivalves) and nektonic (belemnites and ammonites) macrofauna, and also crystalline (magmatic, metamorphic) or carbonate blocks characterized by a low degree of weathering (Wieser, 1948; Koszarski and Nowak, 1960; Szymakowska, 1980). In addition, the almost monospecific assemblages of macrofauna contained belemnites, which show evidence of wave action (Lipnik; Koszarski, and Nowak, 1960).

The formation of these deposits was related to sudden brief transport of sediments downslope over a short distance (Lee et al., 2007; Szydło, 2011). Calcareous bioclastic material was locally supplied. Individual planktonic forms, accompanied by rare benthic forms, were transported in long-distance suspension currents during the Albian-Turonian transition. In the upper part of the Lgota Beds containing spongiolites (AlbianTuronian), agglutinated microfauna were occasionally replaced by calcareous foraminiferal associations, which consist of opportunistic planktonic (Hedbergella, Heterohelix) or benthic forms represented by the genera Osangularia, Lenticulina, Gyroidinoides, Discorbis, Cibicides, and Dentalina (Geroch, 1966; Bak et al., 2005; Szydło, 2008). These calcareous forms inhabited the near-shore environments, and part of them existed under anaerobic conditions (Berhnard, 1986; Koutsoukos et al., 1990); they are usually preserved as moulds composed of pyrite (Geroch, 1966; Bakk, 2000). Similar calcareous benthic foraminifers and mostly reworked calcareous nannoplankton, and also planktonic foraminifera and tintinnids, appeared periodically during the deposition of the Gaize Beds in the AlbianTuronian transition and of the Godula Beds in the Early Turonian (Figs. 3, 4 and 7). Massive corroded tests of deepdwelling planktonic forms (Rotalipora) sensitive to environmental changes (Gaize Beds; Liszkowa, 1956) or better preserved, epifaunal benthic forms belong mainly to active deposit feeders (Berthelina, Gyroidinoides, Valvulineria, Patellina, Cibicides) that are observed in the studied samples of these biosiliceous deposits (Figs. 3 and 4). Benthic foraminifera and calcareous nannoplankton were noted in hemipelagic deposits forming sandstone intercalations, while planktonic foraminifera and tintinnids appeared in hemipelagic and pelagic deposits, which formed as independent lithostratigraphic units. Their relationship was related to short- or long-lasting periods of low tectonic activity and minor eustatic changes, respectively.

During the supply of coarse-grained turbidities into the basin, deep-water circulation was reactivated, the upwelling increased, and the nutrient supplies were more frequent and intense. These factors had an impact on the spread on diverse agglutinated assemblages. In the Albian, assemblages included mainly shallow and surficial epifauna (Plectorecurvoides, Recurvoides, Thalmannammina) accompanied by a few deep infaunal forms such as Gaudryina, Bulbobaculites, and Arenobulimina (Figs. 3, 4 and 7). In the upper part of the Lgota Beds, bacterial and detritus feeders occurred locally in high numbers (Haplophragmoides falcatosuturalis; Geroch, 1966; Geroch and Nowak, 1984; Szydło, 2008). Numerous and diverse agglutinated foraminifera, belonging to shallow or deep infauna, were observed in light grey and green shales of the 


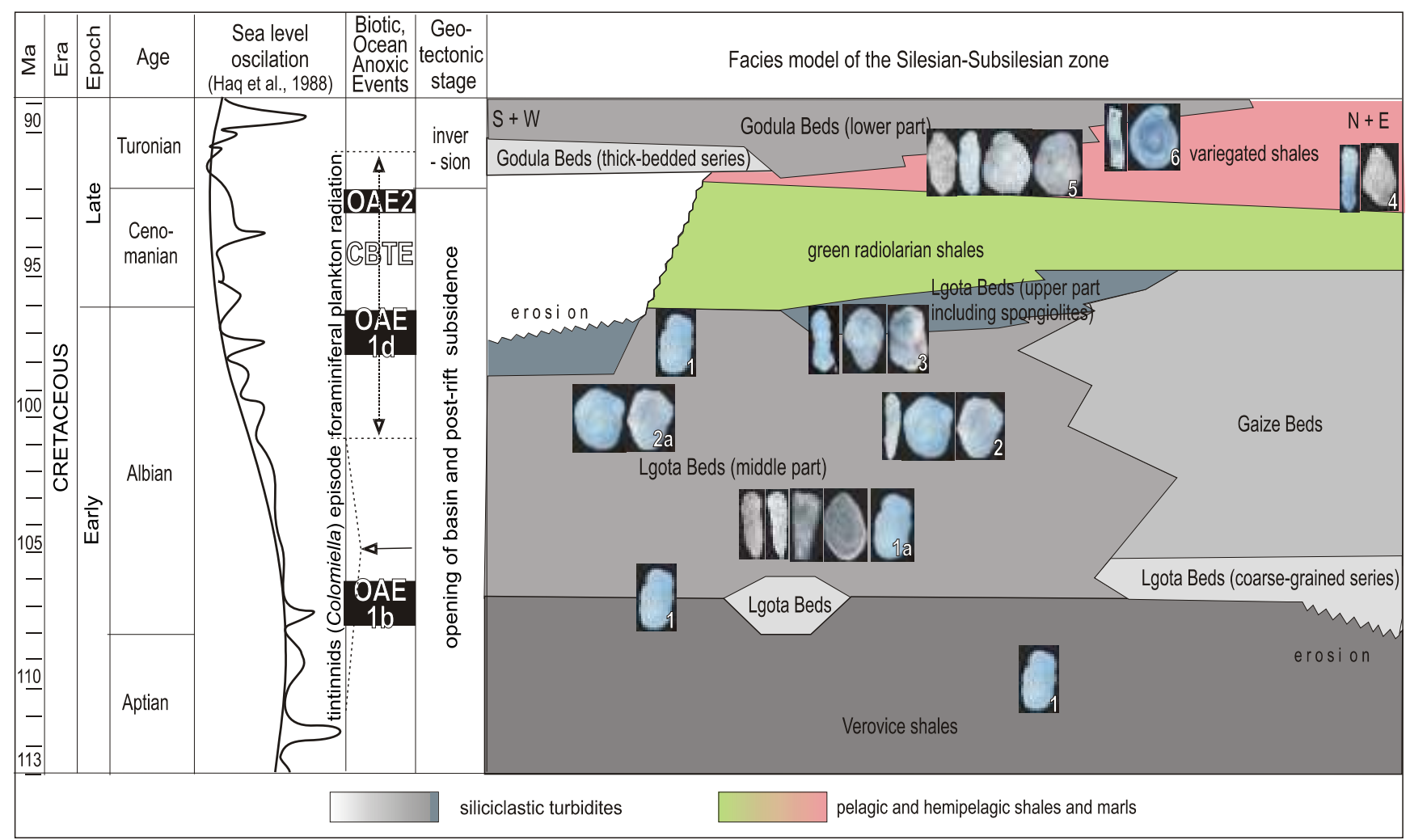

Fig. 7. Faunal changes in agglutinated foraminiferal assemblages in relation to facies models and sea level fluctuations, geotectonic activity, and also oceanic anoxic and biotic events

Assemblages with: 1 - surficial epifauna (Recurvoides), 1a - surficial epifauna (Recurvoides), semi-infauna (Jaculella) and rare deep infauna (Gaudryina, Pseudobolivina), 2 - surficial epifauna (Recurvoides) and shallow infauna (Plectorecurvoides), 3 - numerous mobile (Haplophragmoides) and very rare deep (Bulbobaculites, Arenobulimina) infauna, 4 - very rare deep infauna (Uvigerinammina, Gaudryina), 5 - surficial infauna (Recurvoides) or/and surficial infauna (Uvigerinammina, Gerochammina), 6 - suspension (Nothia) and attached epifauna (Ammodiscus)

Lgota Beds as well as in the Cenomanian-Turonian variegated shales, which occur as intercalations in the lower part of the Godula Beds, or constitute a separate lithological unit. Specimens of shallow infauna (Recurvoides) are numerous, while mobile (Haplophragmoides) and deep infauna (Uvigerinammina, Falsogaudryinella, Gaudryina) rarely occur. The deep infauna (Gerochammina and Uvigerinammina), including active deposit and bacterial feeders, dominated in variegated shales of the Turonian (Figs. 3, 4 and 7). The accompanying epifaunal suspension feeders (Nothia) and forms attached to marine plants (Ammodiscus) are rare. The surface waters were colonized by deep-dwelling planktonic forms (Marginotruncana) at that time (Fig. 3). During the homogeneous sedimentation, an impoverished foraminiferal microfauna existed under the conditions of organic influx and oxygen deficiency, which dominated during the relative sea level rise. In the Early Albian, impoverished agglutinated foraminiferal assemblages, similar to those from the Verovice Shales, persisted under dysaerobic conditions (OAE1b) in the separated parts of the basin. The monospecific agglutinated assemblages known as biofacies $B$ (Severin, 1983; Kuhnt and Kaminski, 1990), including mainly surficial infauna (Recurvoides), which are accompanied by rare deep infauna (Gaudryina, Pseudobolivina) or scarce semiinfauna (Jaculella) and epifauna (Glomospira), appeared in black organic-rich deposits (lower part of the Lgota Beds; Figs. 3 and 7). In this period, plankton, including calcareous dinocysts and tintiniids (Colomiella), probably accumulated in the separated parts of the basin. In the Late Albian and Turonian, intense subsidence and volcanic activity associated with a eustatic sea level rise influenced increased phytoplankton productivity and radiolarian blooms (CBTE). Siliceous plankton productivity and enhanced upwelling led to expanded short-term oxygen minima in the Late Albian (OAE1d) and in the latest Cenomanian (OAE2). In these periods of deficient oxygen levels, agglutinated foraminifers became almost extinct in the bottom waters, while planktonic forms locally survived near the surface (Hedbergella, Heterohelix, Guembelitria) and in surface waters (Rotalipora, Praeglobotruncana; Caron, 1985; Leckie, 1987; Leckie et al., 2002). The first forms occurred in the upper part of the Lgota Beds, including spongiolites, and the latter were noted in the variegated (green and red) shales belonging to the so-called radiolarian beds (Huss, 1957; Liszkowa, 1956). In these pelagic deposits of the Cenomanian-Turonian, the number of dinocysts specific for open areas (Pterodinium) increased (Bak et al., 2000). Forms of this type also occurred periodically in hemipelagic deposits of the Albian (Lgota Beds). This coincided with changes in relative sea level and phytoplankton productivity at the time. 


\section{DISCUSSION}

Changes in fossil assemblages are very closely related with sedimentary processes and environmental parameters, which are shaped by geotectonic and volcanic activities and also sea level fluctuations and anoxic and biotic events. Agglutinated foraminifers are regarded as autochthonous microfauna and therefore are closely related to depositional environments (e.g., Haig, 1979; Olszewska, 1984; Jones and Charnock, 1985; Loubere, 1989; Kuhnt et al., 1989, 1992; Szydło, 2008). The simplification of foraminiferal assemblages may mainly be observed under low oxygen conditions and high organic flux. Agglutinated foraminifers existed as bacterial, deposit, and detritus feeders under dysaerobic conditions in the Early Albian (OAE1b) and the Late Albian (OAE1d). In the long perspective, decay of the organic matter contributed to oxygen consumption in the bottom waters and finally led to the disappearance of benthic life. This was intensified by volcanic activity and a maximal deepening of the basin during pelagic sedimentation. The impoverished assemblages could also reflect the short sedimentation periods just after the sudden supply of coarse-grained material into the basin. In the long perspective, the supply of the sandstones contributed to the increase of water circulation and oxygenation of the basin floor. Consequently, these sedimentation episodes favoured numerous and variable deep water morphotypes, which assembled the second ecological type of foraminiferal assemblages.

Faunal changes in the agglutinated microfauna coincided with the supply of calcareous bioclastic material and caused phytoplankton productivity to fluctuate. This event was probably recorded for the first time in the Early Albian. It was correlated with the occurrence of tintinnids (Colomiella), which are preserved in marly sediments of the Subsilesian Unit (OIszewska, 1997).

Agglutinated foraminiferal assemblages were periodically replaced by planktonic and calcareous benthic foraminifers during the Albian-Turonian transition. At the time of tectonic instability and dynamic changes in sedimentation, calcareous nannoplankton, including mainly forms which were resistant to dissolution, and limestone of the Stramberk type had been supplied. Carbonate rocks, including calcareous nannoplankton, originated mainly from former Jurassic platforms, which were uplifted and eroded intensely in the separated parts of the ba$\sin$. These events coincided with the widespread destruction of sponge "reefs", which provided material for forming the biosiliceous deposits (cherty mudstones and spongiolites). In these settings, organic-walled dinocysts of littoral and low salinity environments dominated.

These organic-walled cysts were replaced gradually by forms characteristic of open seas during the Cenomanian. At that time, planktonic siliceous forms (radiolarians) were widespread. The expansion and radiation of the phytoplankton was related to low tectonic activity and low-energy sedimentation. Deposition of this type dominated in the Subsilesian Zone, while the sedimentation of sponge-rich biosiliciclastic deposits prevailed in the Silesian Zone. Under these conditions specific planktonic foraminifers survived. Their extinction was caused by the formation of the $\mathrm{OMZ}$ in the surface waters during the Late Albian (OAE1d) and the latest Cenomanian (OAE2). Some of these, as eurytopic forms, had a wider ecological tolerance (Heterohelix, Hedbergella, Guembelitria), and other ones, as stenotopic forms, were very environmentally sensitive (Rotalipora, Praeglobotruncana; Leckie, 1987; Gasiński, 1997; Hart, 1999; BouDagher-Fadel, 2013). The first were shallowdwelling forms, while the latter represented deep dwelling microfossils. This sequence of planktonic foraminifers distinctly coincided with the enhanced upwelling that led to the uplift of anoxic waters into the surface at the time.

During the Turonian, the evolution of planktonic foraminifera correlated with dynamic changes in depositional environments, which were induced by the renewed supply of terrigenous material. This material mainly originated from the eastern uplifted parts of the Silesian Basin, formed as the Subsilesian sub-basin, in Cenomanian-Turonian time. The biogenic material, including calcareous skeletal elements of planktonic forms, were locally supplied in that time. These were calcareous nannoplankton of the Jurassic and the Early Cretaceous, and foraminifera of the Turonian-Santonian. Apart from new keeled plankton belonging to Marginotruncana, agglutinated benthos that is represented by forms belonging to Uvigerinammina and Gerochammina occur in foraminiferal assemblages. Faunal changes in foraminiferal associations were correlated with the development of new niches during the sedimentation of variegated calcareous deposition in the Turonian.

\section{CONCLUSIONS}

The sequences of the fossils described were clearly related to sea level changes and also to phytoplankton productivity during the Albian-Turonian. The number, diversity, and preservation of the fossils discussed correspond with oceanic maximum anoxic (OAE1b, OAE1d, OEA2) and biotic (CTBE) events, which can be correlated with geotectonic and volcanic activity in the Outer Carpathian Basin. During and after each type of event there occurred significant faunal changes in foraminiferal assemblages. Usually, the decreased variability and number of the microfauna coincided with dominant siliceous fossils (sponge spicules, radiolarians) during the Late Albian-Cenomanian or the Cenomanian-Turonian. In these intervals, such microfossils were the predominant components of organic-rich deposits (cherty mudstones, spongiolites and radiolarian shales). The spicule-rich deposits included also skeletal elements of macro- and microfossils and also rock clasts from near shore environments and land, which were uplifted and eroded at the time. The accumulation of radiolarian skeletons in large masses coincided with a maximal subsidence and eustatic sea level rise, which previously resulted in radiolarian blooms (CTBE; Thurow, 1988; Baumgartner et al., 1992). Just before and during this event, enhanced volcanic activity and upwelling were associated with an increased surface productivity and the deficiency of oxygen in subsurface waters due to oxidation of organic carbon (Gucwa and Wieser, 1980; Vogt, 1989). This led to expanded and intensified oxygen minima, which coincided with the elimination of life in bottom (agglutinated foraminifers) and then in surface waters (foraminifers, radiolarians and dinocysts). During the Turonian, tectonic reorganization of the basin led to the reactivation of coarse-grained turbidites containing reworked macrofossils and rock blocks similar to those from the Lower Albian thick-bedded deposits, but in low numbers. Finally, coarse-grained deposits were gradually replaced by hemipe- 
lagic variegated shales during the Turonian. At that time, diversified agglutinated and single planktonic foraminifera represented mainly by deep-dwelling forms existed in the bottom or subsurface waters.

Acknowledgements. We thank anonymous reviewers for their constructive comments on the manuscript. We are grateful to Drs T. Malata, and to P. Nescieruk (Carpathian Branch of the Polish Geological Institute-National Research Institute) for his help during fieldwork and geological study. The research was financially supported by the State Committee for Scientific Research grant No N307 005 32/0230 and by the PGI-NRI statutory funds (projects 6.14.0009.00.0 and 6.14.0013.00.0).

\section{REFERENCES}

Alexandrowicz, S., 1973. Gaize-type sediments in the Carpathian Flysch. Neues Jahrbuch für Geologie und Paläontologie Monatshefte, 1: 1-17.

Arthur, M.A., Jenkyns, H.C., Brumsack, H.J., Schlanger, S.O., 1990. Stratigraphy, geochemistry, and palaeoceanography of organic-rich Cretaceous sequences. NATO ASI Series C, Kluwer Academic Publishers, 304: 75-111.

Baumgartner, P.O., Bown, P., Marcoux, J., Mutterlose, J., Kaminski, M., Haig, D., McMinn, A., 1992. Early Cretaceous biogeographic and oceanographic synthesis of Leg 123 (off Northwestern Australia). Proceedings of the Ocean Drilling Program, Scientific Results, 123: 739-758.

Bąk, K., 2007. Deep-water facies succession around the Cenomanian-Turonian boundary in the Outer Carpathian basin: sedimentary, biotic and chemical records in the Silesian Nappe, Poland. Palaeogeography, Palaeoclimatology, Palaeoecology, 248: 255-290.

Bąk, K., Bąk, M., Paul, Z., 2001. Barnasiówka Radiolarian Shale Formation - a new lithostratigraphic unit in the Upper Cenomanian-Lowermost Turonian of the Polish Outer Carpathians (Silesian series). Annales Societatis Geologorum Poloniae, 71 75-103.

Bąk, M., 2000. Radiolaria from the Upper Cenomanian-Lower Turonian deposits of the Silesian Unit (Polish Flysch Carpathians). Geologica Carpathica, 50: 309-324.

Bąk, M., Gedl, E., Bąk, K., 2000. Radiolarian, foraminiferal and dinocysts assemblages at the Cenomanian-Turonian boundary in the Subsilesian unit of the Flysch Carpathians (in Polish). In: Referaty, komunikaty, postery: 17 Konferencja Paleontologów, 21-2309.2000 Kraków; Historia basenów sedymentacyjnych a zapis paleontologiczny (eds. B. Zapałowicz-Bilan et al.): 12-13.

Bąk, M., Bąk, K., Ciurej, A., 2005. Mid-Cretaceous spicule-rich turbidites in the Silesian Nappe of the Polish Outer Carpathians: radiolarian and foraminiferal biostratigraphy. Geological Quarterly, 49 (3): 275-290.

Bernhard, J.M., 1986. Characteristic assemblages and morphologies of benthic foraminifera from anoxic, organic-rich deposits: Jurassic through Holocene. Journal of Foraminiferal Research, 16: 207-215.

Bieda, F., Geroch, S., Koszarski, L., Ksia kiewicz, M., ytko, K., 1963. Stratigraphie des Karpates externes polonaises. Biuletyn Instytutu Geologicznego, 181.

Birkenmajer, K., Gasiński, M.A., 1992. Albian and Cenomanian paleobathymetry in the Pieniny Klippen Belt, Polish Carpathians. Cretaceous Research, 13: 479-485.

Bolli, H.M., Saunders, J.B., Perch-Nielsen, K., 1989. Plankton Stratigraphy: Volume 1, Planktic Foraminifera, Calcareous Nannofossils and Calpionellids. CUP Archive.

Bolli, H.M., Beckmann, J.-P., Saunders, J.B., 1994. Benthic Foraminiferal Biostratigraphy of the South Caribbean Region. Cambridge University Press.

BouDagher-Fadel, M.K., 2013. Biostratigraphic and Geological Significance of Planktonic Foraminifera (2nd ed.). Office of the Vice Provost Research. University College, London.
Bralower, T.J., Thierstein, H.R., 1984. Low productivity and slow deep-water circulation in mid-Cretaceous oceans. Geology, 12: 614-618.

Calvert, S.E., Pederson, T.F., 1992. Organic carbon accumulation and preservation in marine sediments: how important is anoxia? In: Organic Matter: Productivity, Accumulation, and Preservation in Recent and Ancient Sediments (eds. J. Whelan and W. Farrington): 231-263.

Caron, M., 1985. Cretaceous planktic foraminifera. In: Plankton Stratigraphy (eds. H.M. Bolli, E. Saunders and K. Perch-Nielsen): 17-86. Cambridge University Press.

Cavazza, W., Wezel, F.C., 2003. The Mediterranean region - a geological primer. Episodes, 26: 160-168.

Erbacher, J., Thurow, J., 1997. Influence of oceanic anoxic events on the evolution of mid-Cretaceous radiolaria in the North Atlantic and western Tethys. Marine Micropaleontology, 30: 139-158.

Erbacher, J., Thurow, J., Littke, R., 1997. Evolution patterns of radiolaria and organic matter variations: a new approach to identify sea-level changes in mid-Cretaceous pelagic environments. Geology, 24: 499-502.

Erbacher, J., Huber, B.T., Norris, R.D., Markey, M., 2001. Increased thermohaline stratification as a possible cause for an ocean anoxic event in the Cretaceous period. Nature, 409: 325-327.

Gasiński, M.A., 1997. Tethyan-Boreal connection: influence on the evolution of mid-Cretaceous planktonic foraminiferids. Cretaceous Research, 18: 505-514.

Gedl, E., 2001. The latest Albian-Cenomanian age of the Lgota beds from Rzyki quarry (Silesian Nappe, Polish Outer Carpathians) on the basis of dinocyst study (in Polish with English summary). Biuletyn Państwowego Instytutu Geologicznego, 396: 49-50.

Gedl, E., 2003. Biostratygrafia i paleoekologia warstw wierzowskich i lgockich jednostki podśląskiej polskich Karpat zewnętrznych na zachód od Raby w świetle badań palinologicznych (in Polish). Biblioteka Instytutu Nauk Geologicznych, Wydział Biologii i Nauk o Ziemi Uniwersytetu Jagiellońskiego.

Geroch, S., 1966. Lower Cretaceous small Foraminifera of the Silesian series, Polish Carpathians (in Polish with English summary). Rocznik Polskiego Towarzystwa Geologicznego, 36: 413-480.

Geroch, S., Nowak, W., 1980. Stratigraphy of the Flysch in the borehole Łodygowice IG-1 (Western Carpathians). Annales de la Societe Geologique de Pologne, 50: 341-390.

Geroch, S., Nowak, W., 1984. Proposal of zonation for the Late Tithonian-Late Eocene, based upon arenaceous Foraminifera from the Outer Carpathians, Poland. In: Bentos'83; 2nd Int. Symp. Benthic Foraminifera (Pau, April 11-15/4/1983), Elf Aquitaine, Esso REP et Total CFP (ed. H.J. Oertli): 225-239.

Geroch, S., Jednorowska, A., Ksią kiewicz, M., Liszkowa, J., 1967. Stratigraphy based upon microfauna in the Western Polish Carpathians. Biuletyn Instytutu Geologicznego, 211: 185-267.

Golonka, J., Krobicki, M., 2001. Upwelling regime in the Carpathian Tethys: a Jurassic-Cretaceous palaeogeographic and palaeoclimatic perspective. Geological Quarterly, 45 (1): 15-32. 
Golonka, J., Oszczypko, N., Ślączka, A., 2000. Late Carboniferous-Neogene geodynamic evolution and paleogeography of the circum-Carpathian region and adjacent areas. Annales Societatis Geologorum Poloniae, 70: 107-136.

Górka, H., Geroch, S., 1989. Radiolarians from a Lower Cretaceous section at Lipnik near Bielsko-Biała (Carpathians, Poland). Annales Societatis Geologorum Poloniae, 59: 183-195.

Gucwa, I., 1990. Studies on the geochemical correlation of sedimenatry rocks in the Polish Flysch Carpathians (in Polish with English summary). Prace Państwowego Instytutu Geologicznego, 128: 1-58.

Gucwa, I., Wieser, T., 1980. Geochemistry and mineralogy of sedimentary rocks of the Carpathian Flysch rich in an organic matter (in Polish with English summary). Prace Mineralogiczne, 69 7-38.

Haig, D., 1979. Global distribution patterns for Mid-Cretaceous foraminiferids. Journal of Foraminiferal Research, 9: 29-40.

Haq, B.U., Hardenbol, J., Vail, P.R., 1988. Mesozoic and Cenozoic chronostratigraphy and cycles of sea-level change. SEPM Special Publication, 42: 71-101.

Hart, M.B., 1999. The evolution and biodiversity of Cretaceous planktonic Foraminiferida. Géobios, 32: 247-255.

Hay, W.W., DeConto, R.M., Wold, C.N., Wilson, K.M., Voigt, S., Schulz, M., Wold-Rossby, A., Dullo, W.-C., Ronov, A.B., Balukhovsky, A.N., Söding, E., 1999. Alternative global Cretaceous paleogeography. GSA Special Paper, 332: 1-47.

Herrle, J.O., Pross, J., Friedrich, O., Hemleben, Ch., 2003 Short-term environmental changes in the Cretaceous Tethyan Ocean: micropalaeontological evidence from the Early Albian Oceanic Anoxic Event 1b. Terra Nova, 15: 14-19.

Huss, F., 1957. Stratigraphy of the Węglówka unit in the light of its microfauna (in Polish with English summary). Acta Geologica Polonica, 7: 29-62.

Jenkyns, H.C., 1980. Cretaceous anoxic events: from continents to ocean. Journal of Geological Society, 137: 171-188.

Jones, R.W., Charnock, M.A., 1985. "Morphogroups" of agglutinated Foraminifera. Their life positions and feeding habits and potential applicability in (paleo)ecological studies. Revue de Paléobiology, 4: 311-320.

Kaminski, M.A., 2004. The year 2000 classification of the agglutinated Foraminifera. Grzybowski Foundation Special Publication, 8: 237-255.

Koszarski, L., Nowak, W., 1960. Notes on the age of the Lgota Beds (Carpathians Flysch) (in Polish with English summary). Kwartalnik Geologiczny, 4 (2): 468-483.

Koszarski, L., Nowak, W., ytko, K., 1959. Notes on the Godula Beds (Carpathian Flysch) (in Polish with English summary). Kwartalnik Geologiczny, 3 (1): 127-151.

Koutsoukos, E.A.M., Leary, P.N., Hart, M.B., 1990. Latest Cenomanian - earliest Turonian low oxygen tolerant benthic foraminifera: a case study from the Sergipe Basin (NE Brazil) and the Western Anglo-Paris Basin (Southern England). Palaeogeography, Palaeoclimatology, Palaeoecology, 77: 145-177.

Ksia kiewicz, M., 1961. Life conditions in flysch basins. Rocznik Polskiego Towarzystwa Geologicznego, 31: 3-21.

Ksia kiewicz, M., ed., 1962. Geological Atlas of Poland. Cretaceous and Early Tertiary in the Polish External Carpathians. Stratigraphic and Facies Problems, 13. Instytut Geologiczny, Warszawa.

Ksia kiewicz, M., 1975. Bathymetry of the Carpathian Flysch Basin. Acta Geologica Polonica, 25: 309-367.

Kuhnt, W., Kaminski, M.A., 1990. Paleoecology of Late Cretaceous to Paleocene deep-water agglutinated foraminifera from the North Atlantic and western Tethys. In: Paleoecology, Biostratigraphy, Paleoceanography and Taxonomy of Aggilltinated Foraminifera (eds. C. Hemleben, M.A. Kaminski, W. Kuhnt and D.B. Scott): 433-505. NATO ASI Series, Kluwer Academic Publishers.

Kuhnt, W., Kaminski, M.A., Moullade, M., 1989. Late Cretaceous deep-water agglutinated foraminiferal assemblages from the North Atlantic and its marginal seas. Geologische Rundschau, 78: $1121-1140$
Kuhnt, W., Geroch, S., Kaminski, M.A., Moullade, M., Neagu, T., 1992. Upper Cretaceous abyssal claystones in the North Atlantic and Western Tethys: current status of biostratigraphical correlation using agglutinated foraminifera and paleogeographic events. Cretaceous Research, 13: 467-478.

Leckie, R.M., 1987. Paleoecology of mid-Cretaceous planktonic foraminifera: a comparison of open and epicontinental Sea assemblages. Micropaleontology, 33: 164-176.

Leckie, R.M., Bralower, T.J., Cashman, R., 2002. Oceanic anoxic events and plankton evolution: biotic response to tectonic forcing during the mid-Cretaceous. Paleoceanography, 17: 1-13.

Lee, H.J., Locat, J., Desgagnés, P., Parsons, J.D., McAdoo, B.G. Orange, D.L., Puig, P., Wong, F.L., Dartnell, P., Boulanger, E., 2007. Submarine mass movements on continental margins. IAS Special Publication, 37: 213-274.

Liszkowa, J., 1972. Opracowanie profili wzorcowych Karpat na postawie badań biostratygraficznych (mikrofaunistycznych). Jednostka podśląska Karpat zachodnich (in Polish). National Geological Archive (819740), Instytut Geologiczny, Warszawa.

Loeblich, A.R., Tappan, H., 1987. Foraminiferal Genera and their Classification. Van Nostrand Reinhold.

Longoria, J.F., 1973. On the stratigraphic distribution of the Tintinnid genus Colomiella. Boletín de la Sociedad Geológica Mexicana, 34: 97-99.

Loubere, P., 1989. Bioturbation and sedimentation rate control of benthic microfossils taxon abundances in surface sediments: a theoretical approach to the analysis of species microhabitats. Marine Micropaleontology, 14: 317-325.

Neagu, T., Platon, E., 1994. Genera Haplophragmoides Cushman,1910; Recurvoides Earland, 1934; Thalmannammina Pokorny, 1951; Plectorecurvoides Noth, 1952; and Pokornyammina n.gen. from Upper Cretaceous flysch facies, Eastern Carpathians, Romania. Revista Española de Micropaleontologia, 26: 5-30.

Olszewska, B., 1984. A paleoecological interpretation of the Cretaceous and Paleogene foraminifers of the Polish Outer Carpathians. Biuletyn Instytutu Geologicznego, 346: 7-53.

Olszewska, B., 1997. Biofacje polskich Karpat (in Polish). National Geological Archive (876314): 1-41. Państwowy Instytut Geologiczny, Warszawa.

Olszewska, B., Malata, E., 2006. Paleoenvironmental and paleobatymetrical analysis of microfossil assemblages of the Polish Outer Carpathians. In: Paleotectonic Evolution of the Outer Carpathian and Pieniny Klippen Basins (eds. N. Oszczypko, A. Uchman and E. Malata): 64-68. Instytut Nauk Geologicznych Uniwersytetu Jagiellońskiego, Kraków.

Olszewska, B., Szydło, A., 2012. The dark deposits of the Polish Outer Carpathians: implications for anoxic events in the Tethys on the basis of micropaleontological data (Cretaceous-Paleogene). In: Book of Programme and Abstracts. $2^{\text {nd }}$ International Conference Alpine-Petrol 2012 on Geology, Ecology and Petroleum Prospectives of the Carpathians and other Regions in Europe (eds. M.J. Kotarba and M. Wróbel): 91-92.

Omana, L., Torres, J.R., Lopez-Doncel, R., Alencaster, G. Lopez-Caballero, I., 2014. A pithonellid bloom in the Cenomanian/Turonian boundary interval from Cerritos in the $\mathrm{W}$ Valles-SLP Platform, Mexico: paleoenviromental significance. Revista Mexicana de Ciencias Geológicas, 31: 28-44.

Reháková, D., Michalík, J., 1997. Evolution and distribution of calpionellids - the most characteristic constituents of Lower Cretaceous Tethyan microplankton. Cretaceous Research, 18: 493-504.

Robaszynski, F., Zagrarni, M.F., Caron, M., Amédro, F., 2010. The global bio-events at the Cenomanian-Turonian transition in the reduced Bahloul Formation of Bou Ghanem (central Tunisia). Cretaceous Research, 31: 1-15.

Schlanger, S.O., Jenkyns, H.C., 1976. Cretaceous Oceanic Anoxic Events: causes and consequences. Geologie en Mijnbouw, 55: 179-184.

Severin, K.P., 1983. Test morphology of benthic foraminifera as a discrimination of biofacies. Marine Micropaleontology, 8: 65-76. 
Słomka, T., 1995. Deep water siliceous sedimentation of the Godula Beds of Carpathians (in Polish with English summary). Prace Geologiczne, 139.

Stampfli, G.M., Borel, G.D., 2002. A plate tectonic model for the Paleozoic and Mesozoic constrained by dynamic plate boundaries and restored synthetic oceanic isochrons. Earth and Planetary Science Letters, 196: 17-33.

Stampfli, G.M., Mosar, J., Favre, P., Pillevuit, A., Vannay, J.-C., 2001. Permo-Mesozoic evolution of the western Tethys realm: the Neo-Tethys East Mediterranean basin connection. Mémoires du Muséum National d'Histoire Naturelle, Paris, 186 51-108.

Szydło, A., 2008. Faunal changes in mid-Cretaceous deep-water agglutinated foraminifera in the Silesian Basin (Polish Outer Carpathians). Grzybowski Foundation Special Publication, 13: 215-225.

Szydło, A., 2011. Agglutinated foraminifers from mass transport deposits - examples from the Northern Outer Carpathians. Grzybowski Foundation Special Publication, 16: 317-330.

Szymakowska, F., 1980. Egzotyki kredy dolnej z regionu ChełmCzarnorzeki w Środkowych Karpatach (in Polish). Sprawozdania z Posiedzeń Komisji Naukowej PAN Oddział w Krakowie, 22, I-VI 1978: 196-197.
Ślączka, A., Kaminski, M.A., 1998. A guidebook to excursions in the Polish Flysch Carpathians. Grzybowski Foundation Special Publication, 6: 1-177.

Ślączka, A., Geroch, S., Koszarski, L., 1993. Polish flysch Carpathians. Grzybowski Foundation Special Publication, 2: 1-54.

Ślączka, A., Oszczypko, N., Malata, E., Cieszkowski, M., 1999. An early history of the Outer Carpathian basin. Geologica Carpathica, 50, Spec. Issue: 170-172.

Thurow, J., 1988. Cretaceous radiolarians of the North Atlantic Ocean: ODP Leg 103 (Sites 638, 640, and 641) and DSDP Legs 93 (Site 603) and 47B (Site 398). Proceedings of the Ocean Drilling Program, Scientific Results, 103: 379-418.

Trojero, M., 1975. Tintinidos Mesozoicos de Mexico (taxonomía y datos paleobiológicos). Boletin Asociación Mexicana de Geologos Petroleros, 27: 329-449.

Vogt, P.R., 1989. Volcanogenic upwelling of anoxic, nutrient rich water: a possible factor in carbonate-bank/reef demise and benthic faunal extinctions? GSA Bulletin, 101: 1225-1245.

Wieser, T., 1948. Crystalline exotics in the Cretaceous of the Silesian in the vicinity of Wadowice (in Polish with English summary). Rocznik Polskiego Towarzystwa Geologicznego, 18: 109-150. 